\title{
Working with Creativity of Gifted Students through Ludic Teaching
}

\author{
Fernanda Hellen Ribeiro Piske ${ }^{1}$, Tania Stoltz' ${ }^{1}$ Jarci Maria Machado', \\ Carla Luciane Blum Vestena ${ }^{2}$, Carla Sant'ana de Oliveira ${ }^{3}$, \\ Samarah Perszel de Freitas ${ }^{4}$, Cristiana Lopes Machado ${ }^{1}$ \\ ${ }^{1}$ Federal University of Parana, Curitiba, Brazil \\ ${ }^{2}$ Unicentro/UFPR, Guarapuava, Brazil \\ ${ }^{3}$ Unicentro/Faculdade Guairacá, Guarapuava, Brazil \\ ${ }^{4}$ Positivo University, Curitiba, Brazil \\ Email: nandahellen@hotmail.com
}

Received 17 May 2016; accepted 24 July 2016; published 27 July 2016

Copyright (C) 2016 by authors and Scientific Research Publishing Inc.

This work is licensed under the Creative Commons Attribution International License (CC BY). http://creativecommons.org/licenses/by/4.0/

(c) (i) Open Access

\section{Abstract}

Educational practices that develop creativity depend on good teacher training. Teachers should be able to value the potential of their students. Teacher can promote a work with creative educational practices for this which it is necessary to develop in their students the ability to think in terms of possibility to explore various consequences and suggest changes and improvements to their own ideas. Teacher is a facilitator of the teaching-learning process and encourages the interests of their students. He/she should respect their feelings and emotions, allowing that each student has the freedom to express themselves in class in a positive emotional climate. Teacher should respect his/her students in accordance with their needs. Needs can be cognitive, social or emotional. It is possible to emphasize the importance of ludic teaching to attend psychological, cognitive, emotional and social needs of gifted students. Through ludic teaching, teachers can incite the desire to learn of these children and help them to develop their creative potential.

\section{Keywords}

Creativity, Gifted Students, Ludic Teaching

\section{Introduction}

Creativity is a fundamental aspect for gifted education. But the challenge in promoting education that includes

How to cite this paper: Piske, F. H. R., Stoltz, T., Machado, J. M., Vestena, C. L. B., de Oliveira, C. S., de Freitas, S. P., \& Machado, C. L. (2016). Working with Creativity of Gifted Students through Ludic Teaching. Creative Education, 7, 16411647. http://dx.doi.org/10.4236/ce.2016.711167 
creative educational practices is something that is present in many schools (Piske, Stoltz, \& Machado, 2014a; Stoltz, 2016). Piske (2016) explains that these practices can be linked to teacher education that needs to be prepared to attend the needs of their students, especially those who have high abilities, because these students need a school that can attend their special needs and develop their creative potential.

Piske $(2013,2015,2014 \mathrm{a}, 2016)$ points out that the ludic teaching can be defined as the way of teaching through games and educational toys that have aim to develop creativity and student interest. The content proposed by the teaching staff can be more attractive to the student if it is taught in a creative way. Students will be more motivated if the proposed teaching incites their curiosity and desire to learn.

It is important to give options to students to learn fundamental things playing during the process of teaching and learning instead of emphasizing intellectualization in education. For Steiner $(2000,2009,2014)$ early intellectualization is related to the development of future materialism. Materialism is revealed in understanding that everything is matter and has its interest primarily focused on the material things. Steiner (2000) highlights that education should focus on the full development of every human being. His Waldorf Pedagogy is an example of how to improve creativity with a ludic teaching in a broader sense (de Andrade e Silva, 2015; Stoltz, 2016; Stoltz \& Weger, 2012, 2015; Veiga \& Stoltz, 2014; Stoltz, da Veiga, \& Romanelli, 2015).

On the other hand, according to Vygotsky (2008), when child plays, he/she learns to act in a cognitive sphere, rather than a visual external sphere, depending on the internal motivations and trends, and not by the incentives provided by external objects. When child plays, he/she can use his/her imagination.

Stoltz et al. (2015) explains that fantasy is exemplified by Vygotsky as the creative nature of concrete expression in the construction of a new image. Its high point is the achievement of a concrete form, but this can only be obtained with the help of abstraction.

An important opportunity to implement practices which develop creativity of gifted children can be the promotion of a ludic teaching to arouse their curiosity, their imagination and their desire to learn more about their area(s) of interest, as well as make these children deepen their knowledge on various subjects.

\section{Creativity and Giftedness}

For many specialists in the area of Giftedness, creativity is an essential attribute in education, because without creativity the process of teaching and learning is meaningless, and there is no reason to learn with a repetitive and monotonous way, especially when it comes to gifted students, as these children require different teaching to develop their high abilities (Pfeiffer, 2016; Peterson, 2003; Renzulli, 2004; Prieto, Soto, \& Fernandez, 2013; Soriano de Alencar, 2001, 2007, 2011; Pérez, 2004; Piske, 2011, 2013, 2016; Piske \& Stoltz, 2012, 2013; Piske, Stoltz, \& Machado, 2014a, 2014b; among others).

In line with researchers in the area of Giftedness, Renzulli (2004), one of the leading researchers in this area, points out that one of the key factors to identify a gifted child is the creativity that he/she presents, as well of his/her high abilities above average and high levels of commitment to the task. "The gifted and talented children are those who are able to develop this set of traits and apply them to any potentially valuable area of human performance" (Renzulli, 2004: p. 81).

Renzulli (2004) emphasizes the importance of creativity and innovative production, and he values the invention, imagination, the unusual and freedom of expression. The imagination of every child flourishes in ludic activities and through these activities he/she has the opportunity to express his/her fantasy. For Kishimoto (1994), the ludic teaching develops language and the imagination of the child through fun activities it is possible to see the psychological nature and childish inclinations, moreover, the ludic teaching provides the child ways to invent, create and use his/her imagination to create possibilities of findings about various issues.

It is possible to affirm that when the child plays, he/she expresses his/her desires, his/her difficulties, his/her anxieties and feelings that are inserted in every gesture of the game because play is his/her way of expressing his/her emotions through his/her secret language, emotions that arise in his/her heart and that emerge when he/she plays. Bettelheim (1984) indicates that no child plays spontaneously just to spend his/her time. His/her choice is motivated by intimate processes, desires, problems, anxieties. What is happening to the child's mind determines his/her ludic activities; Play is his/her secret language, we should respect even if we do not understand him/her (Bettelheim, 1984: p. 105).

Winnicott (1982) points out that each subject a child or adult can be creative when he/she plays and this ways 
he/she can express his/her whole personality, that is, the play activity enables the development of creativity. According to Leontiev (1992) "only through the toy the required operations can be replaced by others and the object conditions can be replaced by other object conditions with preservation of the actual content of the action" (Leontiev, 1992: p. 62). Every child has the opportunity to interact through ludic activities "he/she internalizes broader knowledge and develops natural and enjoyable way of skills" (Maluf, 2008: p. 21).

In various stages of a child's life, the action of playing is present and belongs to his/her imaginary world where he/she creates games that are also related to his/her reality. Kishimoto (2000) emphasizes that the toy proposes an imaginary world of children and adult, creator of playful object. In the case of the child, the imagery varies according to age: for pre-school of 3 years old, it is charged with animism; from 5 to 6 years old predominantly integrates elements of reality (Kishimoto, 2000: p. 19).

Despite its importance, the act of playing has been questioned by many teachers as an act worthless, meaningless and many of them do not attach due importance to the child's play. Brougère (2000) criticizes the subjects who perceive the toy as a worthless object and explain that if the toy is a smaller object from the point of view of social sciences, it is an object with deep richness. Society shows itself in what happens especially to the children. Therefore, it shows the image of childhood. The toy is one of the developers of our culture, incorporating our knowledge about the child or at least representations widely disseminated that circulate the images that our society is able to segregate (Brougère, 2000: p. 98).

\section{Creativity in Childhood Education in Brazil}

It is essential to note the importance of the ludic space at schools contained in the Curriculum Guidelines for Childhood Education. The pedagogical proposals should include educational measures involving the ludic teaching as something important for the development of creativity, particularly of gifted students who require a differentiated curriculum with additional activities to develop their high skills. Each child has different characteristics and they are the center of curriculum planning, every child has the right to play, fantasize, make questions, create senses of the nature and society and they should have access to culture. The Curriculum Guidelines for Childhood Education point out that the educational proposals of childhood education should consider the child as a historical individual that makes his/her personal and collective identity, she/she learns, observes, experiences, recounts, recognizes senses about nature and society, producing culture (Brazil, 2009: p. 1).

The Special Education Department of MEC in 2006 in Knowledge collection and inclusion practices: developing skills to attend the special educational needs of students who have giftedness, highlights the importance of offering to these children methods for developing their high potential through a learning that is not centered on the teacher. This document points out that is important to offer students opportunities to develop their full potential and in accordance with their abilities, schools need to provide an education for all, this requires a transformative pedagogical action, with more comprehensive methods to their needs and interests, as an alternative to propose offer not teacher-centered learning, but meaningful to the students, respecting their particularities (Brazil, 2006: p. 25).

Educational practices that develop creativity depend on good teacher training. Teachers should be able to value the potential of their students. de Souza Fleith \& Soriano de Alencar (2005) believe that the teacher should promote a work with creative educational practices for this it is necessary to develop in their students the ability to think in terms of possibility to explore various consequences, suggest changes and improvements to their own ideas, "not worrying by the limitations of context; teachers should involve their students to solve real problems" (de Souza Fleith \& Soriano de Alencar, 2005: p. 5).

It is essential that the pedagogical practices promote an enabling environment for creativity. According to Mitjáns Martínez (1997), it is important that teachers consider some relevant factors during classes, such as:

a) freedom, discipline, responsibility, psychological safety, tolerance;

b) the recognition and appreciation of the work and progress of each student, not emphasizing the aspect of evaluation for grades;

c) the teaching process centered on the student, and the teacher facilitator of the teaching-learning process that encourages the development of interests, motives, critical thinking and potential;

d) respect for individuality and therefore should observe the individualization of teaching-learning process;

e) the mobilization of group resources to promote an emotional climate positive among its members. 
Teacher is a facilitator of the teaching-learning process and encourages the interests of their students, he/she should respect their feelings and emotions, allowing that each student has the freedom to express themselves in class in a positive emotional climate. Teacher should respect his/her students in accordance with their needs. Needs can be cognitive, social or emotional.

According to researches in the area of high abilities/giftedness, gifted students may have social, emotional and cognitive difficulties (Silverman, 1993; Schuler, 2000; Coleman \& Cross, 2000; Peterson, 2003; Kane, 2016; Virgolim, 2016; Piske, 2011, 2013, 2014a, 2014b, 2015, 2016; Piske, Stoltz, \& Bahia, 2015; Piske \& Stoltz, 2013; among others); These difficulties can be alleviated with educational practices that promote the development of creativity.

When the child plays, she expresses desire to learn more about what is offered to her, and she feels motivated to carry out her activities in different areas of knowledge. In this sense, a teaching that prime the development of creativity can enhance the high skills and can consequently make the gifted children feel a well-being in class when they develop their creative potential (Besançon \& Lubart, 2008; Gross, 2014; Soriano de Alencar, 2011 , 2014).

According to Piske $(2013,2014 a, 2015,2016)$ the gifted child well-being depends on the motivation he/she receives during learning and how his/her special needs are attended. The proposal for a ludic teaching would be an important way to attend the interests of the child with high potential and through this teaching his/her level of satisfaction can increase in relation to learning.

Ludic teaching may be related to sensitivity, feelings of joy and satisfaction, and the pleasure of learning and freedom of expression. Olivier (2003) points out that understanding of the play is linked with parameters beyond the rationality of innovation to discover new possibilities to find solutions to various areas of knowledge. Olivier (2003: p. 22) indicates five key factors that define ludic teaching:

A-ludic teaching emphasizes creativity, invention and imagination, by its own connection with the fundaments of pleasure.

B-ludic is an end in itself, that is, it is not the means by which we achieve another goal: its goal is the pleasurable experience of its activity;

C-playfulness is spontaneous; thus differs from all activity imposed compulsorily; this is where pleasure and duty are not linked, neither at infinity nor at eternity;

D-playfulness belongs to the dimension of dream, magic, sensitivity; the principles of rationality are not emphasized here;

E-playfulness is based on today: it is concerned with here and now, not the preparation of a non-existent future.

\section{Conclusion}

It is concluded that ludic activities are essential to the development of each child, as well as explains Pereira (2005) that playful teaching provides moments of discovery, construction and understanding of each human being, stimuli for autonomy, for creativity, for personal expression. Ludic activities have a fundamental role in relation to the feelings and emotions of children, including those children with high potential who need specialized services for their special needs.

Gifted children may have social, emotional and cognitive difficulties (Pfeiffer, 2016; Silverman, 1993; Kane \& Silverman, 2014; Coleman \& Cross, 2000; Peterson, 2003; Renzulli, 2004; Soriano de Alencar, 2014; Piske, Stoltz, \& Machado, 2014a, 2014b; Piske, 2016; among others).

In this sense, it is important that educational practices are based on a teaching that develops creativity and enhances the high skills of gifted students so that make these students feel satisfied during the teaching-learning process (Peterson, 2014; Miranda \& Morais, 2014; de Souza Fleith \& Soriano de Alencar, 2005; Soriano de Alencar, 2011, 2014; Piske, 2013, 2014a, 2016). It is possible to emphasize the importance of ludic teaching to attend psychological, cognitive, emotional and social needs of gifted students. Through ludic teaching, teachers can incite the desire to learn of these children and help them to develop their creative potential.

\section{References}

Besançon, M., \& Lubart, T. (2008). Individual Differences in the Development of Creative Competencies in School Children. Learning and Individual Differences, 18, 381-389. http://dx.doi.org/10.1016/j.lindif.2007.11.009 
Bettelheim, B. (1984). Uma vida para seu filho. São Paulo: Artmed, 358 p.

Brazil (2006). Saberes e práticas da inclusão: Desenvolvendo competências para o atendimento às necessidades educacionais especiais de alunos com altas habilidades/superdotação (2th ed.). Brasília: Mec/Seesp (Série: Saberes e práticas da inclusão). http://portal.mec.gov.br/seesp/arquivos/pdf/altashabilidades.pdf

Brazil (2009). Resolução $n^{\circ} 5$ de 17 de dezembro de 2009. Fixa as Diretrizes Curriculares Nacionais para a Educação Infantil. Diário Oficial da União/Brasília, Brasília, 18 de dez. de 2009, nº1/99, seção 1, p. 18.

Brougère, G. (2000). Brinquedo e cultura (3rd ed.). São Paulo: Cortez, 110 p.

Coleman, L. J., \& Cross, T. L. (2000). Social-Emotional Development and the Personal Experience of Giftedness. In K. A. Heller, F. J. Mönks, R. J. Sternberg, \& R. F. Subotnik (Eds.), International Handbook of Research and Development of Giftedness and Talent (2nd ed., pp. 203-212). Oxford: Elsevier.

http://dx.doi.org/10.1016/b978-008043796-5/50015-2

de Andrade e Silva, D. A. (2015). Educação e ludicidade: um diálogo com a Pedagogia Waldorf. Educar em Revista, No. 56, 101-113. http://dx.doi.org/10.1590/0104-4060.41463

de Souza Fleith, D., \& Soriano de Alencar, E. M. L. (2005). Escala sobre o clima para criatividade em sala de aula. Psicologia: Teoria e Pesquisa, 21, 85-91. http://dx.doi.org/10.1590/S0102-37722005000100012

Gross, M. U. M. (2014). Issues in the Social-Emotional Development of Intellectually Gifted Children. In F. H. R. Piske et al. (Orgs.), Altas Habilidades/Superdotação: Criatividade e emoção [High abilities/Giftedness: Creativity and emotion]. Curitiba: Juruá.

Kane, M. (2016). Gifted Learning Communities: Effective Teachers at Work. In F. H. R. Piske et al. (Orgs.), Altas Habilidades/Superdotação: identificação e atendimento [High abilities/Giftedness and Creativity: Identification and specialized service]. Curitiba: Juruá.

Kane, M., \& Silverman, L. K. (2014). Fostering Well-Being in Gifted Children: Preparing for an Uncertain Future. In: F. H. R. Piske et al. (Orgs.), Altas habilidades/Superdotação (AH/SD): Criatividade e emoção [High abilities/Giftedness: Creativity and emotion]. Curitiba: Juruá.

Kishimoto, T. M. (1994). O jogo e a educação infantil. São Paulo: Pioneira.

Kishimoto, T. M. (2000). Jogo, brinquedo, brincadeira e a educação (4th ed.). São Paulo: Cortez, 183 p.

Leontiev, A. N. (1992). Os princípios psicológicos da brincadeira pré-escolar. In L. S. Vigotski, A. R. Luria and A. N. Leontiev, Linguagem, desenvolvimento e aprendizagem (pp. 119-142). São Paulo: Ícone.

Maluf, A. C. M. (2008). Atividades lúdicas para a Educação Infantil: conceitos, orientações e práticas. Petrópolis: Vozes.

Miranda, L. C., \& Morais, F. M. (2014). Enriquecimento criativo e sua promoção em alunos sobredotados. In F. H. R. Piske et al. (Orgs.), Altas habilidades/Superdotação (AH/SD): Criatividade e emoção [High abilities/Giftedness: Creativity and emotion]. Curitiba: Juruá.

Mitjáns Martínez, A. (1997). Criatividade, personalidade e educação. São Paulo: Papirus.

Olivier, G. G. de F. (2003). Lúdico na escola: Entre a obrigação e o prazer. In N. C. Marcellino (Org.), Lúdico, educação e educação física (2. ed., pp. 15-23). Ijuí: Ed: Unijuí.

Pereira, L. H. P. (2005). Bioexpressão: A caminho de uma educação lúdica para a formação de educadores (388 p). Tese (doutorado) - Programa de Pós-Graduação em Educação, Faculdade de Educação, Universidade Federal da Bahia, Salvador.

Pérez, S. G. P. B. (2004). Gasparzinho vai à escola: Um estudo sobre as características do aluno com altas habilidades produtivo-criativo. 2004. Dissertação (Mestrado em Educação)—Faculdade de Educação, Pontifícia Universidade Católica do Rio Grande do Sul, Porto Alegre.

Peterson, J. (2003). Underachievers: Students Who Don't Perform. In J. F. Smutny (Ed.), Underserved Gifted Populations (pp. 307-332). Creskill: Hampton.

Peterson, J. (2014). Paying Attention to the Whole Gifted Child: Why, When, and How to Focus on Social and Emotional Development. In F. H. R. Piske et al. (Orgs.), Altas habilidades/Superdotação (AH/SD): Criatividade e emoção [High Abilities/Giftedness: Creativity and Emotion]. Curitiba: Juruá.

Pfeiffer, S. (2016). Leading Edge Perspectives on Gifted Assessment. In F. H. R. Piske et al. (Orgs.), Altas habilidades/ Superdotação (AH/SD) e Criatividade: Identificação e Atendimento [High Abilities/Giftedness and Creativity: Identification and Specialized Service]. Curitiba: Juruá.

Piske, F. H. R. (2011). Diversidade e inclusão: O direito à educação de alunos superdotados. In X Congresso Nacional de Educação-Educere - I Seminário Internacional de Representações Sociais, Subjetividade e Educação—SIRSSE (pp. 151161). Curitiba. http://educere.bruc.com.br/CD2011/pdf/4341_2306.pdf 
Piske, F. H. R. (2013). O desenvolvimento socioemocional de alunos com altas habilidades/superdotação (AH/SD) no contexto escolar: Contribuições a partir de Vygotsky. Dissertação (Mestrado em Educação), Curitiba: Universidade Federal do Paraná.

Piske, F. H. R. (2014a). Criatividade e inovação na educação de superdotados. In F. H. R. Piske et al. (Orgs.), Altas habilidades/Superdotação (AH/SD): Criatividade e emoção [High Abilities/Giftedness: Creativity and Emotion]. Curitiba: Juruá.

Piske, F. H. R. (2014b). O desafio de promover práticas educacionais para atender a alunos superdotados. In IV Seminário Internacional de Educação de Pinhais, Pinhais.

http://www.pinhais.pr.gov.br/aprefeitura/secretariaseorgaos/educacao/seminario/uploadaddress/o-desafio-de-promover-pra ticas-educacionais-para-atender-a-alunos-superdotados[6917].pdf

Piske, F. H. R. (2015). Aluno (a) com altas habilidades/superdotação (AH/SD): Quem é essa criança? In: V Seminário Internacional de Educação de Pinhais.

http://www.pinhais.pr.gov.br/aprefeitura/secretariaseorgaos/educacao/seminario/anais/2015/aluno(a)\%20com\%20altas $\% 2$ 0habilidades-superdota \%c3\%a 7\%c3\%a3o\%20-\%20fernanda $\% 20$ piske.pdf

Piske, F. H. R. (2016). Alunos com Altas Habilidades/Superdotação (AH/SD): Como identificá-los? In F. H. R. Piske et al. (Orgs.), Altas habilidades/Superdotação (AH/SD) e Criatividade: Identificação e atendimento [High Abilities/Giftedness and Creativity: Identification and Specialized Service]. Curitiba: Juruá.

Piske, F. H. R., \& Stoltz, T. (2012). O desenvolvimento afetivo de alunos superdotados: Uma contribuição a partir de Piaget. Schème: Revista Eletrônica de Psicologia e Epistemologia Genéticas, 4, 149-166. http://www2.marilia.unesp.br/revistas/index.php/scheme/article/view/2400/1953

Piske, F. H. R., \& Stoltz, T. (2013). Criatividade na escola: A necessidade de reavaliar as práticas educacionais aos alunos superdotados. In F. H. Piske, \& S. Bahia (Coods.), Criatividade na escola: O desenvolvimento de potencialidades, altas habilidades/superdotação (AH/SD) e talentos [Creativity at School: Development of Potentials, High Abilities/Giftedness and Talents]. Curitiba: Juruá.

Piske, F. H. R., \& Stoltz, T., \& Bahia, S. (2015). Percepções de famílias de superdotados sobre o processo de ensino-aprendizagem: Um olhar a partir de Piaget. Schème: Revista Eletrônica de Psicologia e Epistemologia Genéticas, 7 , 78-97. http://www2.marilia.unesp.br/revistas/index.php/scheme/article/view/5781/3952

Piske, F. H. R., Stoltz, T., \& Machado, J. (2014a). Creative Education for Gifted Children. Creative Education, 5, $347-352$. http://file.scirp.org/pdf/CE 2014042316202374.pdf

Piske, F. H. R., Stoltz, T., \& Machado, J. (2014b). Creative Educational Practices for Inclusion of Gifted Children. Creative Education, 5, 803-808. http://file.scirp.org/pdf/CE_2014061915205191.pdf

Prieto, M. D., Soto, G., \& Fernández, M. C. (2013). El aula como espacio creativo. In F. H. Piske, \& S. Bahia (Coods.), Criatividade na escola: O desenvolvimento de potencialidades, altas habilidades/superdotação (AH/SD) e talentos [Creativity at School: Development of Potentials, High Abilities/Giftedness and Talents]. Curitiba: Juruá.

Renzulli, J. S. (2004). O que é esta coisa chamada superdotação, e como a desenvolvemos? Uma retrospectiva de vinte e cinco anos. Educação, 27, 75-131.

Schuler, P.A. (2000). Perfectionism and the Gifted Adolescents. Journal of Secondary Gifted Education, 9, 183-196.

Silverman, L. K. (1993). Counseling Needs and Programs for the Gifted. In K. A. Heller, F. J. Mönks, \& A. H. Passow (Eds.), International Handbook of Research and Development of Giftedness and Talent (pp. 631-647). Oxford: Pergamon.

Soriano de Alencar, E. M. L. (2001). Criatividade e educação de superdotados. Petrópolis, RJ: Vozes.

Soriano de Alencar, E. M. L. (2007). Características socioemocionais do superdotado: Questões atuais. Psicologia em Estudo, 12, 371-378. http://dx.doi.org/10.1590/S1413-73722007000200018

Soriano de Alencar, E. M. L. (2011). Criatividade na educação superior na perspectiva de estudantes e professores. In S. M. Wechsler, \& T. C. Nakano (Orgs.), Criatividade no ensino superior: Uma perspectiva internacional (pp. 180-201). São Paulo: Vetor.

Soriano de Alencar, E. M. L. (2014). Ajustamento Emocional e Social do Superdotado: Fatores Correlatos. In F. H. R. Piske et al. (Orgs.), Altas habilidades/Superdotação (AH/SD): Criatividade e emoção [High Abilities/Giftedness: Creativity and Emotion]. Curitiba: Juruá.

Steiner, R. (2000). A filosofia da liberdade: Fundamentos para uma filosofia moderna. São Paulo: Antroposófica.

Steiner, R. (2009). Reconhecimento do ser humano e realização do ensino. São Paulo: Antroposófica: Federação das Escolas Waldorf no Brasil.

Steiner, R. (2014). A cultura atual e a educação Waldorf. São Paulo: Antroposófica: Federação das Escolas Waldorf no Brasil (FEWB). 
Stoltz, T. (2016). Imaginação e criatividade na educação: A necessidade de outro olhar. In F. H. R. Piske et al. (Orgs.), Altas habilidades/superdotação (AH/SD) e criatividade: Identificação e atendimento [High Abilities/Giftedness and Creativity: Identification and Specialized Service]. Curitiba: Juruá.

Stoltz, T., \& Weger, U. (2012). Piaget and Steiner: Science and Art in the Process of Formation. Research on Steiner Education (RoSE), 3, 134-145. http://www.rosejourn.com/index.php/rose/article/viewFile/106/131

Stoltz, T., \& Weger, U. (2015). O pensar vivenciado na formação de professores. Educar em Revista, No. 56, 67-83. http://www.scielo.br/scielo.php?script=sci arttext\&pid=S0104-40602015000200067\&lng=pt\&tlng=pt.10.1590/0104-4060 .41444 http://dx.doi.org/10.1590/0104-4060.41444

Stoltz, T., da Veiga, M., \& Romanelli, R. A. (2015). Apresentação. Educar em Revista, No. 56, 15-18. http://www.scielo.br/scielo.php?script=sci arttext\&pid=S0104-40602015000200015\&lng=en\&tlng=pt.10.1590/0104-406 0.41831 http://dx.doi.org/10.1590/0104-4060.41831

Stoltz, T., Piske, F. H. R., Freitas, M. F. Q., D’Aroz, M. S., \& Machado, J. M. (2015). Creativity in Gifted Education: Contributions from Vygotsky and Piaget. Creative Education, 6, 64-70. http://dx.doi.org/10.4236/ce.2015.61005

Veiga, M., \& Stoltz, T. (Orgs.) (2014). O pensamento de Rudolf Steiner no debate científico. Campinas, SP: Editora Alínea, $247 \mathrm{p}$.

Vygotsky, L. S. (2008). A formação social da mente. São Paulo: Martins Fontes, 1998.

Winnicott, D. W. (1982). A criança e o seu mundo (6 ed., 270 p). Rio de Janeiro: LTC.

\section{Submit or recommend next manuscript to SCIRP and we will provide best service for you:}

Accepting pre-submission inquiries through Email, Facebook, Linkedin, Twitter, etc A wide selection of journals (inclusive of 9 subjects, more than 200 journals)

Providing a 24-hour high-quality service User-friendly online submission system

Fair and swift peer-review system

Efficient typesetting and proofreading procedure

Display of the result of downloads and visits, as well as the number of cited articles

Maximum dissemination of your research work

Submit your manuscript at: http://papersubmission.scirp.org/ 